\title{
Pengaruh Model Pembelajaran Talking Stick Berbantuan Media Audio Visual Terhadap Hasil Belajar IPA Siswa Kelas IV SD
}

\author{
Ni Ketut Astiti Antari \\ SD Negeri 1 Cempaga \\ e-mail: astitiantari00@gmail.com
}

\begin{tabular}{l} 
A R T I C L E I N F O \\
\hline Article history: \\
1 Januari 2020 Received in \\
revised form \\
30 Mei 2020 \\
Accepted 30 Juni 2020 \\
Available online \\
15 Juli 2020 \\
\hline Kata kunci: Talking stick, \\
Audio visual, Hasil belajar \\
Ipa \\
Keywords: \\
talking stick, audio \\
visual, science \\
learning outcomes
\end{tabular}

\begin{abstract}
ABSTRAK
Masalah dari penelitian ini adalah kurangnya guru dalam menggunakan model pembelajaran yang inovatif sehingga siswa tidak termotivasi dalam belajar dan mempengaruhi hasil belajar siswa. Penelitian ini bertujuan untuk mengetahui pengaruh model pembelajaran kooperatif tipe Talking Stick berbantuan media Audio Visual terhadap Hasil Belajar IPA Siswa kelas IV SD. Jenis penelitian ini adalah penelitian eksperimen semu (quasi experiment) dengan rancangan non-equivalent Posttest Only Control Group Design. Populasi penelitian ini berjumlah 169 siswa. Teknik pengambilan sampel yang digunakan dalam penelitian ini adalah teknik random sampling. metode pengumpulan data dilakukan dengan media tes dengan instrumen tes
\end{abstract}

hasil belajar berbentuk pilihan ganda berjumlah 40 soal. metode pengumpulan data dilakukan melalui tes dengan instrumen tes hasil belajar berbentuk pilihan ganda berjumlah 40 soal. Selanjutnya data dianalisis menggunakan uji-t. Hasil penelitian menunjukkan bahwa terdapat pengaruh model pembelajaran talking stick berbantuan media audio visual terhadap hasil belajar IPA siswa kelas IV SD. Selain itu, kelompok siswa yang mengikuti model pembelajaran Talking Stick berbantuan media audio visual memiliki rata-rata skor hasil belajar IPA lebih tinggi dibandingkan model pembelajaran konvensional. Hal ini menunjukkan bahwa model pembelajaran Talking Stick berbantuan media audio visual berpengaruh positif terhadap hasil belajar IPA siswa kelas IV SD. Implikasi dari penelitian ini yaitu memberikan masukan bagi sekolah untuk dapat meningkatkan mutu pendidikan di sekolah tersebut dengan menentukan kebijakan berupa penerapan model pembelajaran inovatif dalam pelaksanaan pembelajaran.

\footnotetext{
ABSTRACT

The problem of this research is the lack of teachers in using innovative learning models so that students are not motivated in learning and this affects student learning outcomes. This study aims to determine the effect of the Talking Stick cooperative learning model assisted by Audio Visual media on the Science Learning Outcomes of Grade IV Elementary Students. This type of research is a quasiexperimental study with a non-equivalent Post-test Only Control Group Design. The population of the study was 169 students. The sampling technique used in this study was a random sampling technique. The method of data collection is done through a test with 40 multiple choice learning outcomes test instruments. Then the data were analyzed using t-test. The results showed that there was an influence of the talking stick learning model assisted by audio visual media on the learning outcomes of Natural Science students in grade IV elementary school. In addition, groups of students who take the Talking Stick learning model assisted by audio-visual media have an average score of science learning outcomes higher than conventional learning models. This shows that the Talking Stick learning model assisted by audio-visual media has a positive effect on the learning outcomes of science students in grade IV elementary school. The implication of this research is to provide input
} 
for schools to be able to improve the quality of education in the school by determining policies in the form of applying innovative learning models in the implementation of learning.

\section{PENDAHULUAN}

Perkembangan IPA tidak hanya ditandai oleh adanya kumpulan fakta saja, tetapi juga ditandai oleh munculnya "metode ilmiah" (scientific methods) yang terwujud melalui suatu rangkaian "kerja ilmiah" (working scientifically), nilai dan "sikap ilmiah" (scientific attitudes). Hakikat IPA menurut Carind \& Sund (dalam (Widi, 2014)) meliputi empat unsur, yaitu: 1) produk: berupa fakta, prinsip, teori, dan hukum; 2) proses: prosedur pemecahan masalah melalui metode ilmiah; metode ilmiah meliputi pengamatan, penyusunan hipotesis, perancangan eksperimen, percobaan atau penyelidikan, pengujian hipotesis melalui eksperimentasi; evaluasi, pengukuran, dan penarikan kesimpulan; 3) aplikasi: penerapan metode atau kerja ilmiah dan konsep IPA dalam kehidupan sehari-hari; 4) sikap: rasa ingin tahu tentang obyek, fenomena alam, makhluk hidup, serta hubungan sebab akibat yang menimbulkan masalah baru yang dapat dipecahkan melalui prosedur yang benar; IPA bersifat open ended. Menurut Harlen (dalam (Manuaba, I.B.N., N.Kusumariyatni, 2014)) menyatakan ilmu pengetahuan alam adalah sebagian besar aktivitas mental dan praktik manusia untuk menghasilkan pengetahuan. Ilmu Pengetahuan Alam (IPA) yang dalam bahasa Inggris disebut Natural Science atau Science merupakan ilmu yang mempelajari gejala-gejala yang terjadi di alam semesta, sehingga terbentuk suatu konsep dan juga prinsip. Sedangkan (Susanto, 2014) menyatakan bahwa IPA adalah usaha seseorang dalam memahami alam semesta melalui suatu pengamatan dan menggunakan prosedur yang sesuai dan dijelaskan menggunakan suatu penalaran sehingga mendapat sebuah kesimpulan.

(Trisnani, 2014) menyatakan bahwa IPA merupakan konsep pembelajaran alam dan mempunyai hubungan yang sangat luas terkait dengan kehidupan manusia. Menurut (Lisdayanti, N.P., I K. Ardana, 2014) Ilmu Pengetahuan Alam (IPA) adalah pelajaran yang menumbuhkan, menanamkan serta mengembangkan sikap ilmiah siswa, pengetahuan serta keterampiran siswa. Pendidikan Ilmu Pengetahuan Alam dipergunakan untuk mempelajari alam secara teratur, maka IPA merupakan proses penemuan bukan hanya kumpulan dari pengetahuan dan konsep-konsep (Depdiknas, 2003). Selain itu, menurut (Bundu, 2006) IPA merupakan ilmu pengetahuan yang belajar mengenai alam atau peristiwa serta kejadian yang terjadi di alam. Sejalan dengan hal tersebut, (Susanto, 2014) juga menyebutkan bahwa IPA merupakan usaha yang dilakukan manusia dalam mengerti serta paham tentang alam semesta melalui pengamatan-pengamatan yang menggunakan prosedur serta disampaikan menggunakan nalar hingga mendapatkan simpulan. IPA berguna untuk mengidentifikasi suatu permasalahan sehingga menemukan solusi pemecahannya (Pranyandari, 2014). Dalam penerapannya, IPA sebaiknya diberikan dengan teknik yang tepat. Oleh karena itu, pembelajaran IPA menekankan pada pemberian pengalaman belajar secara langsung melalui penggunaan dan pengembangan keterampilan proses dan sikap ilmiah.

Namun pada kenyataannya, pembelajaran IPA di SD masih memiliki kendala dalam pembelajarannya. Hal ini dapat dilihat pada hasil wawancara yang dilakukan di SD Gugus V Kecamatan Banjar terkait dengan proses pembelajaran. Kegiatan siswa selama proses pembelajaran cenderung monoton menggunakan metode ceramah 1) siswa hanya membaca buku, 2) guru tidak menggunakan media, model yang menarik dan inovatif dalam proses pembelajaran, 3) guru juga jarang memberikan praktikum kepada siswa, melainkan guru hanya menjelaskan materi kepada siswa. Selain itu didukung pula dengan hasil observasi di SD Gugus V Kecamatan Banjar yang hasilnya sebagai berikut 1) kegiatan belajar masih berpusat kepada guru, kegiatan yang dilakukan siswa hanya membaca buku, dan mengerjakan tugas, 2) pembelajaran menggunakan metode ceramah, 
3) siswa kurang melakukan interaksi bersama teman kelasnya, 4) kurangnya penggunaan model atau media pembelajaran disekolah, 5) rendahnya hasil belajar IPA siswa.

Untuk melengkapi dan memperjelas kegiatan wawancara dan observasi, maka dilakukan kegiatan studi dokumentasi. Permasalahan belajar di SD Gugus V berujung pada hasil belajar IPA siswa yang rendah. Hal ini dapat dilihat dari hasil studi dokumentasi mengenai hasil belajar IPA siswa yang diambil dari hasil UTS siswa disajikan pada Tabel 1 mengenai Rata-rata Nilai UTS IPA di Kelas IV

Tabel 1. Rata-rata Nilai UTS IPA di Kelas IV

\begin{tabular}{|c|c|c|c|c|c|c|c|}
\hline \multirow{2}{*}{ No } & \multirow{2}{*}{ Nama Sekolah } & \multirow{2}{*}{ KKM } & \multirow{2}{*}{$\begin{array}{c}\text { Jumlah } \\
\text { siswa }\end{array}$} & \multicolumn{2}{|c|}{ Tuntas } & \multicolumn{2}{|c|}{ Tidak Tuntas } \\
\hline & & & & Siswa & $(\%)$ & Siswa & $(\%)$ \\
\hline 1 & SDN 3 Pedawa & 60 & 30 & 15 & 50 & 15 & 50 \\
\hline 2 & SDN 4 Pedawa & 60 & 13 & 5 & 38,5 & 8 & 61,5 \\
\hline 3 & SDN 1 Sidetapa & 65 & 18 & 9 & 50 & 9 & 50 \\
\hline 4 & SDN 2 Sidetapa & 62 & 32 & 14 & 43,8 & 18 & 56,3 \\
\hline 5 & SDN 3 Sidetapa & 60 & 19 & 10 & 52,6 & 9 & 47,4 \\
\hline 6 & SDN 1 Cempaga & 71 & 40 & 9 & 22,5 & 31 & 77,5 \\
\hline 7 & SDN 2 Cempaga & 62 & 17 & 6 & 35,3 & 11 & 64,7 \\
\hline & Jumlah & - & $\begin{array}{c}169 \\
\text { orang }\end{array}$ & $\begin{array}{c}68 \\
\text { orang }\end{array}$ & 40,23 & $\begin{array}{c}101 \\
\text { orang }\end{array}$ & 59,76 \\
\hline
\end{tabular}

(Sumber: Guru Kelas IV di Gugus V Kec. Banjar)

Berdasarkan tabel 1 Rata-rata Nilai UTS IPA di Kelas IV diperoleh jumlah keseluruhan siswa kelas IV di Gugus V Kecamatan Banjar Tahun Pelajaran 2019/2020. Ternyata dari 169 siswa, masih terdapat 101 siswa atau sama dengan 59,76\% siswa yang belum mencapai KKM. Bila dikonversikan pada Penilaian Acuan Patokan (PAP) (Agung, 2016) perolehan hasil belajar IPA siswa tergolong rendah. Hal tersebut merupakan masalah yang dialami oleh SD di Gugus V Kecamatan Banjar. Oleh karena itu, perlu adanya penerapan model pembelajaran yang dapat meningkatkan hasil belajar siswa. Salah satu model pembelajaran yang dapat meningkatkan hasil belajar IPA siswa adalah Model Pembelajaran Kooperatif Tipe Talking Stick.

Talking Stick (tongkat berbicara) adalah model yang awalnya dipergunakan oleh penduduk asli Amerika untuk mengajak semua orang berbicara atau menyampaikan pendapat dalam suatu forum (pertemuan antar suku) (Huda, dalam(Hanafi, 2015)). Talking Stick (tongkat berbicara) adalah salah satu alternatif yang awalnya dipergunakan oleh penduduk asli Amerika dalam penyampaian pendapat di suatu forum(pertemuan antarsuku) agar dapat giliran secara merata (Shoimin, 2014). Huda (dalam Zulfa, 2015) Juga menyatakan bahwa Taking Stick merupakan model pembelajaran kooperatif dengan bantuan tongkat. Susilowati (dalam(Asri, B.W., K.Nurhalim, 2019)) menyatakan bahwa talking stick is a method that is used by many teachers for their students for improving four skills, especially in this speaking skill.

Talking Stick dipakai sebagai tanda seseorang mempunyai hak suara (berbicara) yang diberikan secara bergiliran atau bergantian. Hal ini sesuai dengan pernyataan Kurniasih (dalam(Nugraheni, 2016)) yang menyatakan bahwa model pembelajaran Talking Stick dimainkan dengan menggunakan tongkat, tongkat dipergunakan sebagai giliran untuk menyampaikan pendapat atau jawaban dari pertanyaan yang diberikan guru setelah siswa mendapatkan pelajaran. Strategi pembelajaran ini berbantuan tongkat, dimana siswa pemegang tongkat harus menjawab pertanyaan dari yang diberikan oleh guru. Pembelajaran Talking Stick tepat jika diterapkan di sekolah dasar. Disamping melatih kemampuan berbicara, pembelajaran dengan bantuan tongkat ini akan menciptakan suasana yang membangkitkan semangat dan partisipasi aktif peserta didik.

Selain model pembelajaran talking stick, perlu juga media pembelajaran yang membantu siswa belajar. Media yang baik digunakan dalam pembelajaran yaitu media 
audio visual. Menurut Sadiman, dkk. (dalam (Isran., 2018)), media adalah suatu bentuk perantara atau pengantar pesan dari pengirim ke penerima. Saat pembelajaran, media sangat membantu guru untuk menyampaikan pembelajaran. Media audiovisual adalah suatu media yang mempunyai unsur suara dan unsur gambar. Jenis media ini mempunyai kemampuan yang lebih baik, karena meliputi kedua jenismedia auditif (mendengar) dan visual (melihat). Media audio visual merupakan sebuah pearlatan yang berbentuk audio visual atau memadukan unsur pendengaran dan pengelihatan sehingga pembelajaran lebih mudah dipahami siswa.

Media audio visual menurut Rohani (dalam(Mariadeni, K.E., N.T Renda, 2017)) merupakan media instruksional modern yang sesuai dengan perkembangan zaman (kemajuan ilmu dan teknologi), meliputi media yang dapat dilihat, didengar dan yang dapat dilihat dan didengar. Jadi media audio visual adala media yang mempunyai unsur suara dan unsur gambar. Media audio visual termasuk dalam multimedia yaitu jenis media yang selain mengandung unsur suara juga mengandung unsur gambar yang dapat dilihat, seperti misalnya rekaman video, berbagai ukuranfilm, slide suara dan lain sebagainya. Padapenggunaan media audio visual disini menggunakan rekaman video. Menurut Munir (dalam(Fadhli, 2015)) Video adalah Teknologi penangkapan, perekaman, pengolahan, dan penyimpanan, pemindahan, dan perekonstruksian urutan gambar diam dengan menyajikan adegan-adegan dalam gerak secara elektronik. Media audio visual adalah merupakan media perantara atau penggunaan materi dan penyerapannya melalui pandangan dan pendengaran sehingga membangun kondisi yang dapat membuat siswa mampu memperoleh pengetahuan, keterampilan, atau sikap (Ismiati, 2017).

Dengan adanya perpaduan model talking stick dalam belajar dan media audio visual, maka pembelajaran IPA akan menarik bagi siswa, serta mempermudah pemahaman siswa dalam belajar. Hal inilah yang nantinya akan dapat meningkatkan hasil belajar IPA siswa. Berdasarkan permasalahan yang ada, maka dilakukan penelitian model talking stick berbantuan media audio visual terhadap hasil belajar IPA. Adapun tujuan dari penelitian ini untuk mengetahui pengaruh model pembelajaran talking stick berbantuan media audiovisual terhadap hasil belajar IPA.

\section{METODE}

Penelitian ini termasuk dalam jenis penelitian kuantitatif, penelitian kuantitatif menurut Watson (dalam (Danim, 2002)) pendekatan kuantitatif merupakan salah satu upaya pencarian ilmiah (scientific inquiry) yang didasari oleh filsafat postivisme logika (logical positivism) yang beroperasi dengan aturan-aturan yang ketat mengenai logika, kebenaran, hukum-hukum dan prediksi. Penelitian kuatintatif selalu melibatkan data berupa angka, data yang berupa angka ini kemudian diolah secaara statistik dan dilakukan analisa sehingga memperoleh suatu kesimpulan. Rancangan penelitian yang digunakan dalam penelitian ini adalah non-equivalent Post-test Only Control Group Design. Terdapat dua kelompok yang menjadi sampel penelitian yaitu kelompok eksperimen dan kelompok kontrol. Kelompok eksperimen yaitu dengan diberi perlakuan berupa model pembelajaran Talking Stick berbantuan media audio visual, sedangkan kelompok kontrol tidak diberi perlakuan khusus, tetapi perlakuan seperti biasanya dengan menerapkan pembelajaran secara konvensional. Populasi adalah keseluruhan subjek penelitian (Arikunto, 2013). Populasi dalam penelitian ini adalah seluruh siswa kelas IV SD Gugus V Kecamatan Banjar Kabupaten Buleleng Tahun Pelajaran 2019/2020. Banyaknya anggota populasi dalam penelitian ini adalah 169 orang siswa yang tersebar ke dalam tujuh Sekolah di Gugus V Kecamatan Banjar.

Sampel merupakan bagian dari suatu populasi, pengambilan sampel harus mewakili populasi yang ada. Teknik pengambilan sampel yang digunakan dalam penelitian ini adalah teknik random samplingyang di random kelas sebagai intaks group. Teknik ini diambil agar seluruh populasi mendapatkan kesempatan yang sama untuk dijadikan sampel penelitian dan karena tidak memungkinkkannya dilakukan pengacakan 
terhadap individu. Dari enam sekolah populasi dipilih 2 sampel yang akan dijadikan sampel penelitian yaitu SDN 1 Cempaga dan SDN 2 Sidetapa. Sebelum sampel dipilih maka dilakukan terlebih dahulu uji kesetaraan terhadap sampel yang akan digunakan. Berdasarkan hasil uji kesetaraan diperoleh hasil fhitung $<$ Ftabel $0,0058<2,16$. Hal ini menunjukan bahwa nilai UTS siswa kelas IV gugus V Kecamatan Banjar adalah setara. Oleh karena itu, dilanjutkan dengan teknik undian. Berdasarkan teknik undian, diperoleh hasil siswa kelas IV SDN 1 Cempaga sebagai kelas eksperimen dan SDN 2 Sidetape sebagai kelas kontrol.

Metode yang digunakan untuk mengumpulkan data pada penelitian ini adalah metode tes. Tes adalah salah satu alat yang dapat digunakan untuk mengukur kemampuan siswa dalam mengikuti suatu pelajaran. Pada penelitian ini tes yang digunakan adalah tes hasil belajar IPA. Tes hasil belajar IPA digunakan untuk mengukur sejauh mana kemampuan siswa dalam memahami materi IPA yang telah diajarkan oleh guru. Instrumen penelitian adalah alat yang digunakan untuk mengumpulkan data penelitian. Jenis instrumen yang digunakan pada penelitian ini adalah tes hasil belajar IPA siswa kelas IV SD yang dimana soal tes akan dibuat dalam bentuk pilihan ganda sebanyak 40 soal. Tes hasil belajar ini disesuaikan juga dengan indikator materi IPA kelas IV SD semester genap yang ada pada silabus. Tes hasil belajar disusun dengan langkah-langkah (1) Mengidentifikasi standar kompetensi, (2) Mengidentifikasikan kompetensi dasar, (3) Menindentifikasikan indikator pembelajaran, (4) Menyusun kisi-kisi tes, (5) Menentukan kriteria penilaian, (6) Menyusun butir-butir soal, (7) Uji ahli, (8) Uji lapangan,(9) Analisis uji lapangan berupa; uji validitas butir soal, uji reliabilitas butir soal, uji daya beda butir soal, dan tingkat kesukaran butir soal,(10) Revisi butir-butir tes hasil belajar,dan (11) Finalisasi instrumen.

Data yang diperoleh dalam penelitian ini adalah hasil belajar IPA siswa yang merupakan data kuantitatif dan dianalisis dengan statistik inferensial. Statistik inferensial adalah semua penyelidikan yang didasarkan atas data statistik beserta petunjuk-petunjuk tentang ketelitian dan kemantapan dari keputusan yang diambil berdasarkan teori probabilitas. Teknik ini digunakan menganalisis data yang dilakukan dengan cara menyusun secara sistematis dalam bentuk angka-angka atau presentase suatu objek yang diteliti sehingga sehingga di peroleh kesimpulan umum. Untuk menentukan tinggi rendahnya kualitas variabel-variabel, skor rata-rata (mean) tiap-tiap variabel dikonversikan dengan menggunakan kriteria rata-rata ideal $\left(\mathrm{M}_{\mathrm{i}}\right)$ dan standar deviasi ideal $\left(\mathrm{SD}_{\mathrm{i}}\right)$ Sebelum dilakukan pengujian untuk mendapatkan simpulan, maka data yang diperoleh perlu diuji normalitas, homogenitasnya, dan pada penelitian ini digunakan uji- $t$ satu ekor (ekor kanan) dengan taraf signifikan 5\% t-test untuk mengetahui pengaruh model pembelajaran talking stick berbantuan media audio visual terhadap hasil belajar IPA siswa kelas IV SDN 1 Cempaga sebagai kelas eksperimen dan kelas kontrol siswa kelas IV SDN 2 Sidetape yang tidak menerapkan model pembelajaran talking stick berbantuan media audio visual pada mata pelajaran IPA.

\section{HASIL DAN PEMBAHASAN}

1. HASIL

Penelitian ini dilaksanakan dalam delapan pertemuan di kelompok eksperimen maupun di kelompok kontrol, di mana pada kelompok eksperimen diberikan tujuh kali treatment dan satu kali post-test, sedangkan pada kelompok kontrol tujuh kali pembelajaran dan satu kali post test. Adapun deskripsi data dari kedua kelompok tersebut, yaitu kelompok eksperimen dan kelompok kontrol adalah sebagai berikut. Deskripsi data hasil penelitian ini memaparkan rata-rata, median, modus, standar deviasi, varian, minimum, maksimum, dan rentang dari data hasil belajar IPA siswa kelas IV SD N 1 Cempaga dan siswa kelas IV SD N 2 Sidetapa tahun pelajaran 2019/2020 baik untuk kelas yang dibelajarkan dengan menerapkan model pembelajaran kooperatif tipe Talking Stick berbantuan media Audio Visual, maupun siswa yang dibelajarkan dengan 
menerapkan model pembelajaran konvensional. Perhitungan tersebut dikerjakan dengan bantuan program pengolahan angka Microsoft Office Excel 2007dan SPSS 25. Hasil deskripsi data hasil belajar kelompok eksperimen dan kelompok kontrol dapat dilihat pada tabel 2 mengenai Ringkasan Analisis hasil belajar IPA kelompok eskperimen dan kelompok kontrol berikut ini.

Tabel 2. Ringkasan Analisis hasil belajar IPA Kelompok Eksperimen dan Kelompok Kontrol

\begin{tabular}{cccc}
\hline No & Hasil Analisis & Kelompok Eksperimen & Kelompok Kontrol \\
\hline 1 & N & 40 & 32 \\
2 & Mean & 24,83 & 21,72 \\
3 & Median & 25,10 & 21,75 \\
4 & Modus & 25,70 & 21,50 \\
5 & Standar Deviasi & 3,08 & 2,99 \\
6 & Varian & 9,48 & 8,92 \\
7 & Skor Maksimal & 30 & 27 \\
8 & Skor Minimal & 19 & 17 \\
\hline \multicolumn{4}{r}{ (Sumber: Hasil belajar IPA Kelompok Eksperimen dan Kelompok Kontrol) }
\end{tabular}

Berdasarkan tabel di atas, rata-rata skor hasil belajar, untuk kelompok eksperimen melalui model pembelajaran kooperatif tipe Talking Stick berbantuan media Audio Visualadalah 24,83 dengan varian sebesar 9,48 dan standar deviasi 3,08. Skor maksimal yang diperoleh siswa adalah 30, sedangkan skor minimal yang diperoleh adalah 17 . Sedangkan rata-rata skor hasil belajar untuk kelompok kontrol melalui model pembelajaran konvensional adalah 21,72 dengan varian sebesar 8,92 dan standar deviasi 2,99. Skor maksimal yang diperoleh siswa adalah 27 , sedangkan skor minimal yang diperoleh adalah 17. Berdasarkan data tersebut, skor hasil belajar IPA pada kelompok eksperimen melalui model pembelajaran kooperatif tipe Talking Stick berbantuan media Audio Visual, lebih tinggi dari kelompok kontrol dengan model pembelajaran konvensional.

Berdasarkan Mean Ideal dan Standar Deviasi Ideal, maka dapat ditentukan rentangan skor dari masing-masing kategori seperti disajikan pada tabel 3 mengenai Konversi Hasil Post-Test Kelompok Kelompok Kontrol sebagai berikut:

Tabel 3. Konversi Hasil Post-Test Hasil Belajar IPA

\begin{tabular}{ccc}
\hline No & Rentangan Skor & Kategori \\
\hline 1 & $23 \leq 30$ & Sangat Baik \\
\hline 2 & $18 \leq 23$ & Baik \\
\hline 3 & $13 \leq 18$ & Cukup \\
\hline 4 & $8 \leq 13$ & Tidak Baik \\
\hline 5 & $0 \leq 8$ & Sangat Tidak Baik \\
\hline & (Sumber: Hasil Analisis Konversi Post Test Hasil Belajar IPA)
\end{tabular}

Berdasarkan skor hasil belajar IPA kelompok eksperimen diperoleh hasil 30 siswa memperoleh skor dengan kategori sangat baik, dan 10 siswa memperoleh skor dengan kategori baik. Skor rata-rata hasil belajar IPA siswa kelompok eksperimen adalah 24,83. Berdasarkan hasil konversi, dapat dinyatakan bahwa rata-rata skor hasil belajar IPA siswa pada kelompok eksperimen termasuk dalam kategori sangat baik dan berdasarkan skor hasil belajar IPA kelompok kontrol diperoleh hasil 13 siswa memperoleh skor dengan 
kategori sangat baik, 16 siswa memperoleh skor dengan kategori baik, dan 3 orang memperoleh skor dengan kategori cukup. Skor rata-rata hasil belajar IPA siswa kelompok kontroladalah 21,72. Berdasarkan hasil konversi, dapat dinyatakan bahwa rata-rata skor hasil belajar IPA siswa pada kelompok kontrol termasuk dalam kategori baik.

Statistik inferensial yang digunakan adalah uji-t, namun sebelum analisis dengan uji-t, maka terlebih dahulu harus memenuhi beberapa asumsi statistik yaitu Uji Normalitas dan Uji Homogenitas. Uji normalitas dilakukan untuk menguji apakah suatu distribusi empirik mengikuti ciri-ciri normal. Uji normalitas data dilakukan terhadap data post-test hasil belajar IPA kelas eksperimen dan kontrol. Perhitungan dibantu dengan menggunakan SPSS 25. Adapun kriteria pengujian jika signifikansi $>0,05$, maka $\mathrm{H}_{0}$ diterima dan data berdistribusi normal, sedangkan jika signifikansi $<0,05$, maka $\mathrm{H}_{0}$ ditolak dan data tidak berdistribusi normal.

Berdasarkan analisis yang dilakukan, pada tabel 4. di bawah ini disajikan hasil uji coba sebaran data dengan bantuan SPSS sebagai berikut.

Tabel 4. Hasil Uji Normalitas

\begin{tabular}{lllll}
\hline \multicolumn{5}{c}{ Kolmogorov-Smirnov $^{\mathrm{a}}$} \\
\hline & Kelompok & Statistik & df & Sig. \\
\hline \multirow{2}{*}{ Hasil Belajar } & Eksperimen & 0,124 & 40 & 0,126 \\
& Kontrol & 0,131 & 32 & 0,174 \\
\hline \multirow{2}{*}{ Hasil Belajar } & Eksperimen & & 1 & 0,782 \\
& Kontrol & & 1 & 0,783 \\
\hline
\end{tabular}

(Sumber: Uji Normalitas dan Uji Homogenitas

Kolmogorov Smirnov Berbantuan SPSS 25)

\section{PEMBAHASAN}

Dari hasil perhitungan mengguakan rumus kolmogorov smirnov dengan bantuan SPSS 25 , tes hasil belajar IPA siswa kelompok eksperimen $0,126>0,05$. yang berarti data hasil post-test siswa kelompok eksperimen berdistribusi normal. Sedangkan data hasil post-test kelas kontrol $0,174>0,05$, yang berarti data hasil post-test kelompok kontrol berdistribusi normal. Berdasarkan data hasil post-test terbukti baik kelompok eksperimen maupun kelompok kontrol berdistribusi normal.

Uji homogenitas dilakukan pada kelompok eksperimen dan kontrol dengan menggunakan bantuan SPSS 25 dengan kriteria data jika sig. $>0,05$, maka $\mathrm{H}_{0}$ diterima dan varians homogen, sedangkan jika sig. $<0,05$, maka $\mathrm{H}_{0}$ ditolak dan varians tidak homogen. Rangkuman hasil uji homogenitas adalah sebagai berikut.

Berdasarkan Tabel 4, dapat dilihat bahwa sig. pada Based in Mean 0, 782>0,05, sehingga $\mathrm{H}_{0}$ diterima dan varians homogen. Hal ini menunjukkan bahwa data kelompok eksperimen dan kelompok kontrol memiliki varians yang homogen. Setelah data hasil belajar IPA kelompok eksperimen dinyatakan berdistribusi normal dan homogen maka dilanjutkan dengan uji hipotesis. Uji hipotesis menggunakan uji-t, hasil uji t ditampilkan pada tabel 5. Hasil Uji-t sebagai berikut:

Tabel 5. Hasil Uji-t

\begin{tabular}{ccccccccc}
\hline & \multicolumn{8}{c}{ Independent Samples Test } \\
\cline { 2 - 8 } & t & df & $\begin{array}{c}\text { Sig.(2- } \\
\text { tailed) }\end{array}$ & $\begin{array}{c}\text { Mean } \\
\text { Difer } \\
\text { rence }\end{array}$ & $\begin{array}{c}\text { Std.Error } \\
\text { Difer } \\
\text { rence }\end{array}$ & $\begin{array}{c}\text { 95\% Cinfidence } \\
\text { Interval of the } \\
\text { Difference } \\
\text { Lower }\end{array}$ \\
Uper
\end{tabular}




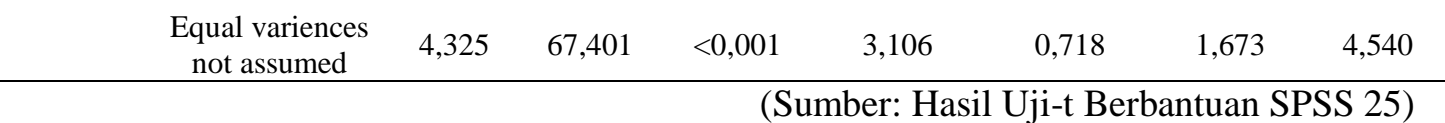

Berdasarkan ringkasan hasil Uji t dengan bantuan SPSS, diperoleh hasil nilai sig. (2-tailed) $0,001<0,05$. Dengan demikian $\mathrm{H}_{0}$ ditolak, yang artinya terdapat pengaruh model pembelajaran talking stick berbantuan media audio visual terhadap hasil belajar IPA siswa kelas IV SDN Gugus V Kecamatan Banjar, Kabupaten Buleleng.

Penerapan model pembelajaran Talking Stick di sekolah dasar, memberikan kesempatan kepada masing-masing peserta didik secara merata untuk dapat mengajukan pendapat atau menjawab pertanyaan. Dengan begitu guru dapat mengetahui siswa yang belum memahami pembelajaran, dengan yang sudah memahami pembelajaran. Di satu sisi, siswa juga akan merasa terpacu untuk belajar karena ia akan diberikan pertanyaan secara acak sehingga harus mengandalkan pengetahuan sendiri. Model pembelajaran talking stick adalah model pembelajaran yang mempergunakan tongkat sebagai alat bantu dalam proses pembelajaran agar tercapainya tujuan dari pembelajaran.

Talking Stick dipakai sebagai tanda seseorang mempunyai hak suara (berbicara) yang diberikan secara bergiliran atau bergantian. Hal ini sesuai dengan pernyataan Kurniasih (dalam(Nugraheni, 2016)) yang menyatakan bahwa model pembelajaran Talking Stick dilakukan dengan bantuan tongkat, tongkat dijadikan sebagai jatah atau giliran untuk berpendapat atau menjawab pertanyaan dari guru setelah siswa mempelajari materi pelajaran. Tongkat dijalankan dari satu siswa ke siswa lain sambil bernyanyi dan berhenti sampai lagu yang dinyanyikan selesai. Yang terakhir mendapatkan tongkat ialah yang harus menjawab pertanyaan dari guru. Permasalahan yang digunakan pada model pembelajaran ini adalah pedoman kurikulum yang telah tersedia.

Model Talking Stick merupakan salah satu model yang menekankan pada keterlibatan siswa pada proses belajar mengajar. Model ini dapat memberikan motivasi kepada siswa supaya belajar aktif dalam memahami dan menemukan konsep, sehingga siswa mampu menghubungkan soal dengan teori yang ada, misalnya pada bagian contoh soal yang merupakan bagian dari bahan belajar siswa dapat digunakan untuk menggambarkan teori, konsep dari materi pembelajaran yang dibahas dalam diskusi antara siswa dengan guru.

Keefektifan penerapan model pembelajaran talking stick juga didukung dengan kelebihan model pembelajaran talking stick (Hasan, R.H., H.Ngatiyo, 2013) antara lain (1) Siswa mempersiapkan pembelajaran dari rumah karena menguji kesiapannya. (2) Materi dapat dikuasai dengan cepat oleh siswa. (3) Meningkatkan semangat belajar siswa. (4) Kemampuan mengemukakan pendapat siswa semakin terasah. Dengan kelebihan itulah yang dapat menyebabkan model ini tepat diterapkan pada siswa sekolah dasar.

Selain model pembelajaran inovatif yang dapat meningkatkan aktifitas dan motivasi belajar siswa, pembelajaran dibantu pula dengan media pembelajaran yaitu audio visual. Penggunaan media audio visual dapat mempertinggi perhatian anak dengan tampilan yang menarik. Selain itu, anak akan takut ketinggalan jalannya video tersebut jika melewatkan dengan mengalihkan konsentrasi dan perhatian. Media audio visual yang menampilkan realitas materi dapat memberikan pengalaman nyata pada siswa saat mempelajarinya sehingga mendorong adanya aktivitas diri.

Selain itu, penggunaan media audio visual dapatmemudahkan siswa dalam memahami materi saat pembelajaran berlangsung. Karena dapat memberikan pengalaman yang bermakna yang belum pernah dilihat sebelumnya dan dapat meningkatkan gairah belajar pada siswa serta memudahkan siswa dalam memahami sesuatu yang abstrak menjadi sesuatu yang konkrit seperti yang dikemukakan oleh Benni Agus Pribadi (dalam(Musfiqon, 2012)), media pembelajaran memberikan kemudahan siswa dalam belajar serta memudahkan guur dalam menyampaikan materi, memberikan pengalaman lebih nyata kepada siswa, serta mengaktifkan semua indera siswa. Penggunaan media ini 
membuat siswa lebih fokus dan tertarik mengikuti proses pembelajaran karena siswa memiliki pengalaman dan pengetahuan baru setelah menyimak apa yang ditayangkan pada media (Wijayanti, N.N., N.W.Arini, 2017).

Adapun langkah model pembelajaran talking stick berbantuan media audio visual yaitu (1) guna menyampaikan tujuan dari pembelajaran. Langkah ini, guru menyampaikan tujuan pembelajaran dan siswa menyimak. (2) Membentuk kelompok. Langkah ini, siswa membentuk kelompok yang satu kelompok terdiri dari 5 sampai 6 orang. Langkah (3) yaitu penguraian materi utama. Pada langkah ini siswa menyimak penjelasan materi pokok dari guru, siswa menanyakan hal-hal yang kurang jelas dan belum dipahami siswa. Pada langkah ini guru menggunakan media audio visual berupa video pembelajaran dalam membantu penyamaian materi agar siswa lebih mudah memahami materi. Langkah selanjutnya (4) yaitu membaca atau mempelajari materi. Kegiatan ini dilaksanakan sebelum melaksanakan kegiatan talking stick. Setelah masingmasing kelompok memahami materi, selanjtnya guru mempersilakan anggota kelompok untuk menutup isi bacaan. Kemudian tongkat dipersiapkan guru dan memberikannya kepada salah satu anggota kelompok. Siswa yang memegang tongkat diberikan pertanyaan oleh guru. Tongkat diputar secara bergilir dari satu siswa kesiswa lainnya hingga seuruh siswa mendapat giliran. Dalam hal ini guru bertugas sebagai pemberi intruksi untuk mulai dan berhentinya tongkat. Langkah selanjutnya yaitu menyimpulkan. Setelah semua siswa mendapatkan giliran untuk menjawab guru mengajak siswa untuk membuat kesimpulan. Setelah itu siswa mengerjakan tes evaluasi yang telah disiapkan guru. Terakhir langkah penutup. Pada tahap ini siswa melakukan refleksi pembelajaran.

Dengan langkah model pembelajaran talking stick berbantuan media audio visual siswa akan termotivasi dalam belajar sehingga sejalan dengan peningkatan hasil belajarnya. Keberhasilan penggunaan model pembelajaran talking stick berbantuan media audio visual juga didukung oleh hasil penelitian yang dilakukan oleh (Mariadeni, K.E., N.T Renda, 2017) yang berjudul "Pengaruh Model Pembelajaran Talking Stick Berbantuan Media Audio Visual Berbasis Kearifan Lokal terhadap Hasil Belajar". Hasil penelitiannya menunjukkan bahwa terdapat perbedaan yang signifikan hasil belajar PKn antara kelompok siswa yang dibelajarkan dengan model pembelajaran Talking Stick Berbantuan media audio visual berbasis kearifan lokal dan kelompok siswa yang tidak dibelajarkan dengan menggunakan model pembelajaran Talking Stick Berbantuan media audio visual berbasis kearifan lokal. Dengan demikian model pembelajaran Talking Stick Berbantuan media audio visual berbasis kearifan lokal berpengaruh positif terhadap hasil belajar PKn siswa. Hasil penelitian tersebut juga didukung oleh hasil penelitian yang dilakukan oleh (Wahyuni, K.A., I W. Wiarta, 2019) yang berjudul "Pengaruh Model Pembelajaran Talking Stick Berbantuan Media Audio Visual terhadap Perkembangan Bahasa Anak Kelompok B". Hasil penelitiannya menunjukkan bahwa model pembelajaran talking stick berbantuan media audio visual berpengaruh terhadap perkembangan bahasa kelompok B TK Santa Maria Ratu Rosari Tahun Ajaran 2018/2019. Berdasarkan dukungan penelitian tersebut, meskipun dalam mata pelajaran yang berbeda, namun model talking stick berbantuan media audio visual yang diterapkan dalam pembelajaran dapat membantu siswa belajar, sehingga tujuan pembelajaran dapat tercapai. Adapun implikasi teoretis dalam penelitian ini yaitu pemilihan model pembelajaran yang tepat berpengaruh terhadap hasil belajar IPA siswa. Sedangkan implikasi praktis dalam penelitian ini yaitu 1) guru berpeluang mengembangkan pembelajaran untuk membangkitkan semangat belajar siswa sehingga tujuan pembelajaran dapat tercapai, yang dapat dilihat dari hasil belajar siswa yang meningkat, 2) memberikan masukan bagi sekolah untuk dapat meningkatkan mutu pendidikan di sekolah tersebut dengan menentukan kebijakan berupa penerapan model pembelajaran inovatif dalam pelaksanaan pembelajaran. 


\section{SIMPULAN}

Berdasarkan rangkuman di atas, dapat disimpulkan bahwa terdapat pengaruh model pembelajaran talking stick berbantuan media audio visual terhadap hasil belajar IPA siswa kelas IV SDN Gugus V Kecamatan Banjar, Kabupaten Buleleng. Selain itu, kelompok siswa yang mengikuti model pembelajaran Talking Stick berbantuan media audio visual memiliki rata-rata skor hasil belajar IPA lebih tinggi dibandingkan model pembelajaran konvensional. Hal ini menunjukkan bahwa model pembelajaran Talking Stick berbantuan media audio visual berpengaruh positif terhadap hasil belajar IPA siswa kelas IV SD Gugus V Kecamatan Banjar, Kabupaten Buleleng tahun pelajaran 2019/2020. Berdasarkan simpulan, berikut beberapa saran yang diberikan terkait model pembelajaran yang diterapkan yakni kepada siswa diharapkan dapat mengikuti pembelajaran dengan menggunakan model serta media pembelajaran untuk meningkatkan hasil belajarnya, guru diharapkan menggunakan model inovatif dalam mengajar siswa agar pembelajaran lebih bermakna bagi siswa sehingga tujuan pembelajaran dapat tercapai, Kepala Sekolah diharapkan dapat menentukan kebijakan pembelajaran di sekolah agar setiap guru menerapkan model pembelajaran dan media pembelajaran inovatif agar memperoleh kualitas pendidikan yang bermutu, dan peneliti lain diharapkan dapat mengembangkan penelitian ini dengan menambahkan variabel penelitia, sehingga dapat memberikan sumbangsih positif mengenai pembelajaran di skeolah dasar bagi dunia pendidikan.

\section{DAFTAR RUJUKAN}

Agung, A. A. G. (2016). Statistika Dasar untuk Pendidikan. Deepublish.

Arikunto, S. (2013). Dasar-dasar Evaluasi Pendidikan. Bumi Aksara.

Asri, B.W., K.Nurhalim, dan P. S. (2019). The Implementation of Talking Stick Model Assisted by Audio-Visual Media Toward Positive Character and Learning Outcome. Journal of Primary Education, 8. https://journal.unnes.ac.id/sju/index.php/jpe/article/ view/26487/11655

Bundu, P. (2006). Penilaian Keterampilan Proses dan Sikap Ilmiah (Dalam Pembelajaran Sains Sekolah Dasar). Depdiknas.

Danim, S. (2002). . Menjadi Peneliti Kualitatif. Pustaka Setia.

Depdiknas. (2003). Undang-Undang RI No.20 tahun 20003. Tentang sistem pendidikan nasional.

Fadhli, M. (2015). Pengembangan Media Pembelajaran Berbasis Video Kelas IV Sekolah Dasar. Jurnal Dimensi Pendidikan Dan Pembelajaran, 3.

Hanafi, P. . (2015). Komparasi Metode Talking Stickdan Student Teams Achievement Division(STAD) Serta Pengaruhnya Terhadap Hasil Belajar Sosiologi Siswakelas XI IPS SMA Negeri 8 Surakartatahun Pelajaran 2014/2015. Jurnal FKIP Universitas Sebe; as Maret.

Hasan, R.H., H.Ngatiyo, H. A. (2013). Penerapan Talking Stick untuk Motivasi Belajar Mata Pelajaran IPA Kelas III SDN 04 Pontianak. Jurnal Pendidikan Dan Pembelajaran Khatulistiwa,

http://jurnal.untan.ac.id/index.php/jpdpb/article/view/660

Ismiati. (2017). Peningkatan Kecerdasan Naturan Anak Melalui Media Audio Visual. Jurnal Ilmiah Pendidikan Anak, 1.

Isran., R. dan. (2018). Manfaat Media dalam Pembelajaran. AXIOM, 7. 
http://jurnaluinsu.ac.id

Lisdayanti, N.P., I K. Ardana, I. B. G. S. (2014). Pengaruh Model Pembelajaran Kooperatif Talking Stick Berbantuan Media Gambar terhadap Hasil Belajar IPA Siswa Kelas V SD Gugus 4 Baturiti. E-Journal Mimbar PGSD Universitas Pendidikan Ganesha, 2.

Manuaba, I.B.N., N.Kusumariyatni, I. M. C. W. (2014). Pengaruh Metode Talking Stick terhadap Hasil Belajar IPA Siswa Kelas V SD Negeri 1 Karangasem Tahun Pelajaran 2013/2014. Mimbar PGSD Undiksha, 2.

Mariadeni, K.E., N.T Renda, dan I. K. S. (2017). Pengaruh Model Pembelajaran Talking Stick Berbantuan Media Audio Visual Berbasis Kearifan Lokal terhadap Hasil Belajar. E-Journal PGSD Universitas Pendidikan Ganesha, 5.

Musfiqon. (2012). Pengembangan Media\& Sumber Pembelajaran. Prestasi Pustaka Raya.

Nugraheni, A. (2016). Studi Komparasi antara Strategi Talking Stick dengan Strategi Make A Match terhadap Hasil Belajar IPA Siswa Kelas IV SDN Kedungjenar Blora Tahun Ajaran 2015/2016 [Universitas Muhammadiyah Surakarta]. https://core.ac.uk/download/pdf/148611369.pdf

Shoimin, A. (2014). 68 Model Pembelajaran Inovatif dalam Kurikulum 2013. Ar-Ruzz Media.

Susanto, A. (2014). Teori Belajar Pembelajaran di Sekolah Dasar. Kencana Prenadamedia Group.

Trisnani, I. dkk. (2014). Evaluasi Program Pembelajaran IPA. ”. Jurnal Teknologi Informasi Komunikasi Pendidikan, 2.

Wahyuni, K.A., I W. Wiarta, I. W. D. (2019). Pengaruh Model Pembelajan Talking Stick Berbantuan Media Audio Visual terhadap Perkembangan Bahasa Anak Kelompok B. Jurnal Pendidikan Anak Usia Dini, 7. https://ejournal.undiksha.ac.id/index.php/JJPAUD/ article/view/18765/12574

Widi, A. (2014). Metodologi Pembelajaran IPA. Bumi Aksara.

Wijayanti, N.N., N.W.Arini, N. K. S. (2017). Pengaruh Model Pembelajaran Kooperatif Tipe Talking Stick Berbantuan Media Audio Visual Terhadap Hasil Belajar IPS. EJournal PGSD Universitas Pendidikan Ganesha, 5. 